\title{
Ocular ultrasonography of sea turtles
}

\author{
Caterina Muramoto', Vinícius Cardoso-Brito', Ana Cláudia Raposo', Thais Torres Pires² \\ and Arianne Pontes Oriá ${ }^{*}$ (iD
}

\begin{abstract}
Background: Environmental changes contribute to the development of ophthalmic diseases in sea turtles, but information on their eye biometrics is scarce. The aim of this study was to describe ophthalmic ultrasonographic features of four different sea turtle species; Caretta caretta (Loggerhead turtle; $n=10)$, Chelonia mydas (Green turtle; $\mathrm{n}=8$ ), Eretmochelys imbricata (Hawksbill turtle; $\mathrm{n}=8$ ) and Lepidochelys olivacea (Olive ridley; $\mathrm{n}=6$ ) under human care. Corneal thickness, scleral ossicle width and thickness, anterior chamber depth, axial length of the lens, vitreous chamber depth and axial globe length were measured by B-mode sonography with a linear transducer. Carapace size and animal weight were recorded. A sonographic description of the eye structures was established.

Results: The four species presented an ovate eyeball, a relatively thin cornea, and a small-sized lens positioned rostrally in the eye bulb, near the cornea, resulting in a shallow anterior chamber. The scleral ossicles did not prevent the evaluation of intraocular structures, even with a rotated eye or closed eyelids; image formation beyond the ossicles and measurements of all proposed structures were possible. B-mode sonography was easily performed in all animals studied. The sonographic characteristics of the eye were similar among the four species. Since there was a correlation between the size of the eye structures and the size of the individual, especially its carapace size, the differences found between E. imbricata and Caretta caretta are believed to be due to their overall difference in size.

Conclusions: Sonography is a valuable tool in ophthalmic evaluation of these species. Only minor differences were found between the species in this study, reinforcing their phylogenetic proximity and their similar functions and habitats.
\end{abstract}

Keywords: Caretta caretta, Chelonia mydas, Eretmochelys imbricate, Eye, Lepidochelys olivacea, Ultrasound

\section{Background}

Sea turtles have different methods for orientation and spatial localization [1], and vision is one of the main senses involved in environmental interactions, hunting and defence against predators [2-6]. The retina of these species changes throughout their lives to adapt to different visual stimuli, resulting from the various environments with which they are in contact, both terrestrial and pelagic, during the migration process [7]. Sea turtles can

\footnotetext{
*Correspondence: arianneoria@ufba.br

${ }^{1}$ School of Veterinary Medicine and Zootechny, Federal University

of Bahia, Avenida Adhemar de Barros, 500, Ondina, Salvador, BA 40170-110, Brazil

Full list of author information is available at the end of the article
}

differentiate colours and, like other aquatic species, they have spherical lenses which are the main means of light refraction in water [8].

The sea turtle's eye is proportionally small relative to its body size in comparison to other vertebrates, and the pupil and lens are small relative to the eye [4]. Other characteristics of these animals' ocular structures are a high sensitivity to corneal touch, strong eyelids, the presence of a well-developed nictitating membrane, scleral ossicles, eyelid scales, retractor bulbi and pyramidalis muscles [4, 9-11], which have a protective function. However, ophthalmic diseases such as corneal ulcers, keratitis and fibropapillomas are not uncommon in these animals $[10,12-15]$ and can cause loss of visual function,

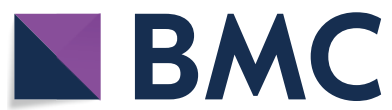

(c) The Author(s) 2020. This article is licensed under a Creative Commons Attribution 4.0 International License, which permits use, sharing, adaptation, distribution and reproduction in any medium or format, as long as you give appropriate credit to the original author(s) and the source, provide a link to the Creative Commons licence, and indicate if changes were made. The images or other third party material in this article are included in the article's Creative Commons licence, unless indicated otherwise in a credit line to the material. If material is not included in the article's Creative Commons licence and your intended use is not permitted by statutory regulation or exceeds the permitted use, you will need to obtain permission directly from the copyright holder. To view a copy of this licence, visit http://creativeco mmons.org/licenses/by/4.0/. The Creative Commons Public Domain Dedication waiver (http://creativecommons.org/publicdomain/ zero/1.0/) applies to the data made available in this article, unless otherwise stated in a credit line to the data. 
thereby restricting the possibility of their reintroduction to, or survival in their natural habitat [16].

Anthropic action and environmental changes contribute to the development of ophthalmic diseases in these animals [13] and are the main causes for their conservation classification status as vulnerable and critically endangered species [17-20]. Among the seven known sea turtle species, five are found along the Brazilian coast: loggerhead turtle (Caretta caretta), hawksbill turtle (Eretmochelys imbricata), olive ridley turtle (Lepidochelys olivacea), green turtle (Chelonia mydas) and leatherback turtle (Dermochelys coriacea) [12, 17-21].

Imaging techniques, such as ultrasound, can contribute to morphological and structural assessments of the eye. Echobiometric eye evaluation has already been employed in chelonians [22, 23], but there are no such studies for sea turtle eyes. Herein we describe sonographic features of the eyes of four sea turtle species, compare the findings among them, and provide anatomical details that could be useful for personnel involved in sea turtle conservation.

\section{Methods}

\section{Sea turtles}

Eyes $(n=64)$ from 32 juvenile to adult sea turtles (10 Caretta caretta, 8 Chelonia mydas, 8 Eretmochelys imbricata and 6 Lepidochelys olivacea) kept at the TAMAR Project (Brazil) visitors centre (VC) were used in the study. The VC tanks fulfil the Standard Permit Conditions for Care and Maintenance of Captive Sea Turtles [24]. Physical and ophthalmic examinations were performed by the technical staff (TAMAR Project) and a veterinary ophthalmologist (UFBA). All animals were subjected to clinical evaluation, and inspection of the eye and periocular region in normal light for gross abnormalities with a $3 \mathrm{X}$ binocular magnifying loupe and trans illuminator. Animals that presented any clinical signs of systemic disease or gross eye or periocular abnormalities were excluded from the study.

All animals were manually restrained and body weight (BW), curved carapace length (CCL) and curved carapace width $(\mathrm{CCW})$ were measured prior to ultrasonographic evaluation. Environmental temperature and humidity ranged from 23.7 to $28.9^{\circ} \mathrm{C}$ and from 57 to $85 \%$, respectively.

\section{Ultrasonographic evaluation}

Prior to ultrasonographic evaluation, one drop of topical anaesthetic (1\% tetracaine hydrochloride with $0.1 \%$ phenylephrine hydrochloride, Anestesico ${ }^{\circledR}$, Allergan, São Paulo, Brazil) was administered to each eye; this dosage was sufficient to perform the ultrasound evaluation for up to $20 \mathrm{~min}$. A portable ultrasound system, Logiq-e ${ }^{\circledR}$
(GE Medical Systems, Wuxi, China), with a 7-12 MHz linear transducer was used. Among the system pre-sets, the "small/superficial parts" were chosen. The ultrasound acoustic gel (Carbogel ULT ${ }^{\circledR}$, São Paulo, Brazil) was placed on the probe surfaces and the transducer was gently propped on either the eyelid or directly on the corneal surface (Fig. 1A). B-mode scanning of the eyeball was performed in sagittal, dorsal and oblique planes by the same investigator $(\mathrm{CM})$ to minimize inter examiner measurement errors. Doppler mode scanning was used to verify the presence of vascularization in some structures, such as the retina, choroid and scleral cartilage.

At the level of the central optic axis of the eyeball, at its maximal anteroposterior axis, corneal thickness $(\mathrm{CT})$, anterior chamber depth (ACD), axial length of the lens (ALL), vitreous chamber depth (VCD) and axial globe length (AGL) were measured (Fig. 1B), and by slightly shifting the transducer laterally or medially, an image of the full scleral ossicle was obtained, and scleral ossicle width and thickness (SOT) were measured (Fig. 1C). The AGL was measured from the corneal surface to the fundus, not including the thick part of the scleral cartilage that surrounds the posterior half of the bulb.

\section{Statistical analyses}

Shapiro-Wilk normality test was used for the physical body measurements and sonographic ocular measurements. SPSS version 22.0 was used for the analysis, and the level of significance was set to $5 \%$. Comparison of the variables between right and left eyes was performed by Wilcoxon test. Kruskal-Wallis test was used for comparison of the same variable between species. Spearman test was used for correlations among BW, CCL, AGL and ocular ultrasound variables.

\section{Results}

The ocular ultrasound images were obtained trans-palpebrally and trans-corneally, with no difference in the image quality. It was possible to identify the bulb's oval shape, and maximum circumference was along the plane perpendicular to the central optic axis (Fig. 1D). It was possible to see almost the entire length of the bulb in all four species, but in some eyes, the extremities of the larger circumference (equatorial diameter) were covered by the posterior acoustic shadow produced by the orbital bones (Fig. 1D), preventing their accurate measurements. Spontaneous rotation of the eye bulb occurred relatively frequently and the examiner had to wait for spontaneous repositioning to obtain the image on the central optic axis.

The cornea was visualized as a convex, smooth and thin hyperechogenic double line with a hypo to anechoic area between the lines. The anterior and posterior segments 


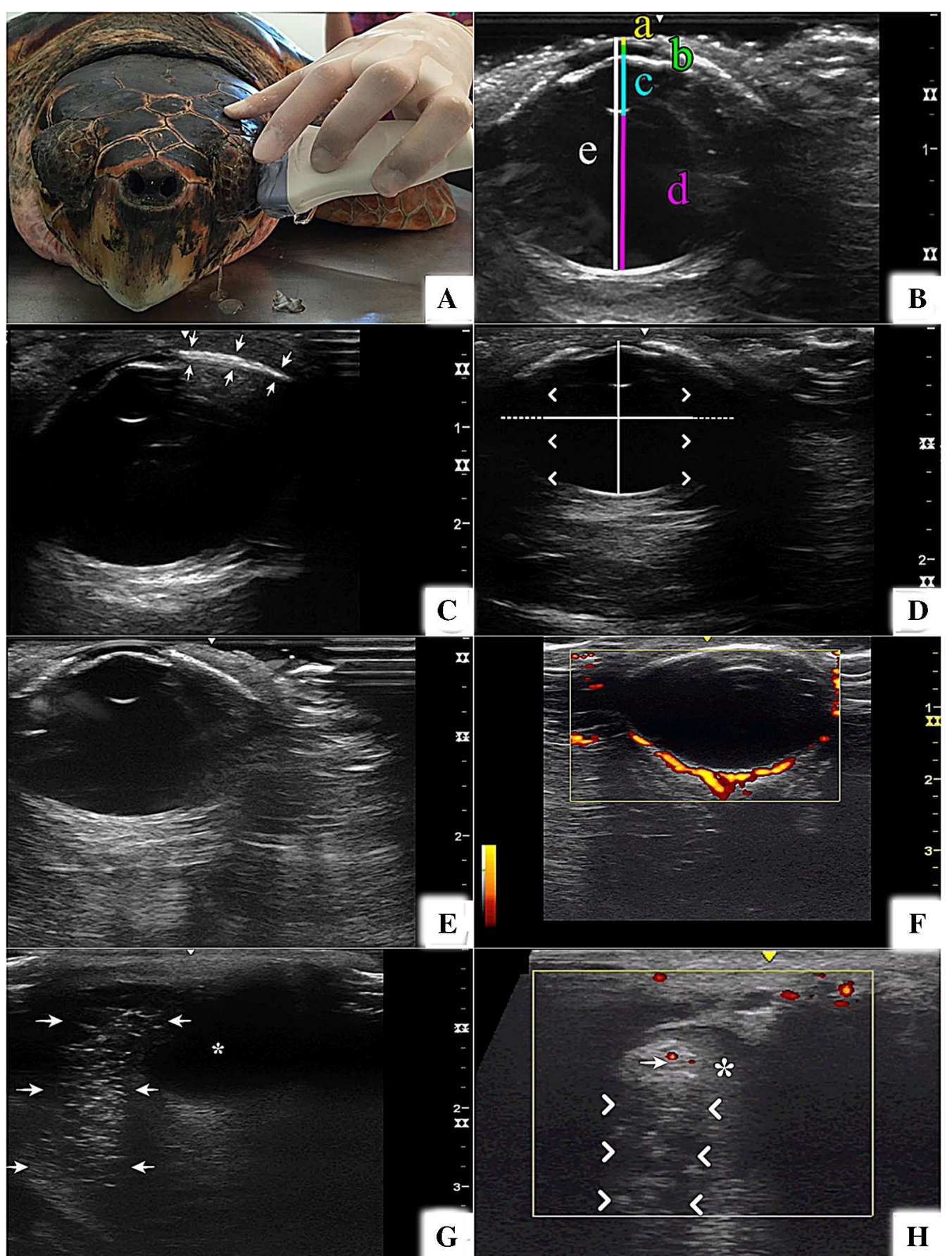

Fig. 1 Ultrasound images of sea turtle eyes. A Examination of a Caretta caretta eye. B Chelonia mydas eye-coloured lines show the axial globe length (a), corneal thickness (b), anterior chamber depth (c), lens axial length (d), vitreous chamber depth (e). C Caretta caretta eye- - slightly oblique image from which scleral ossicle width and thickness were measured (between arrows). D Eretmochelys imbricata eye showing oval shape with central optic axis (line) smaller than the equatorial diameter (dashed line), indicating the posterior shading of the orbit bone (asterisk). E Lepidochelys olivacea eye - note that despite the posterior ossicle artefacts, visualization of the posterior portions is not impeded. $\mathbf{F}$ Caretta caretta eye in power Doppler mode showing segments of blood vessels (in yellow-orange) distributed in the scleral cartilage. G Part of the salt gland (between arrows) adjacent to the bulb (*) of Lepidochelys olivacea. $\mathbf{H}$ Caretta caretta eye in power Doppler mode showing a large blood vessel (*) adjacent to the salt gland (between arrows), where few and small vessels were identified (arrow head) 


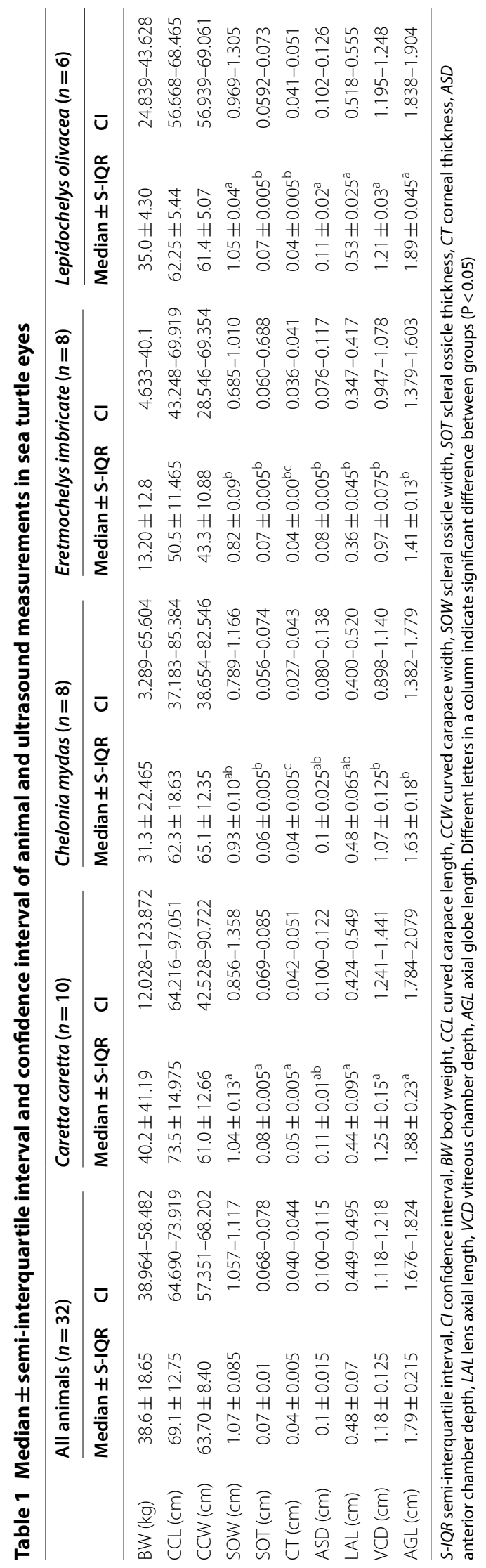


were filled with homogeneous anechoic fluid. The lens had an almond-like biconvex shape, with smooth, slender, hyperechogenic anterior and posterior surfaces, and a homogeneous anechoic central portion. The ciliary body and iris were viewed together as a circular echogenic band positioned anterior to the lens equator.

The scleral ossicle was easily identified as a thin, slightly convex hyperechogenic structure that surrounds the bulb as a strip, from the corneal border (limbus) to the anterior sclera, and it could be measured (anteroposterior measurement and thickness). The scleral ossicle had a slightly coarse echotexture and, depending on the angle of insonation, it produced a discrete acoustic shadow and/or posterior reverberation. However, in both cases, the artefacts were discrete and did not prevent imaging beyond the scleral ossicles (Fig. 1E).

The scleral cartilage is a tissue present in the sclera of sea turtles, which surrounds the back of the bulb, posteriorly to the retina and choroid. It was identified as a thick and echogenic tissue with interspersed hyperechogenic foci, which gave the tissue a coarse echotexture; the scleral cartilage had an irregular posterior surface and poorly defined limits towards adjacent retrobulbar tissues and choroid. Several segments of blood vessels were identified interspersed with the scleral cartilage in some individuals using power or colour Doppler mode (Fig. 1F).

The optic nerve was observed as a homogeneous, hypoechogenic tubular structure and its insertion into the bulb could not be visualized on the image of the central optic axis. Parts of the salt gland could be evaluated and showed a rough echotexture with irregular contours and mixed echogenicity (Fig. 1G). In several individuals, a large blood vessel with slowly flowing contents adjacent to the gland, was observed. In the Doppler mode evaluation, a few small vessels were identified inside the salt gland in some individuals (Fig. 1H).

The measured values presented a non-parametric distribution $(\mathrm{P}<0.05)$. There were no significant differences between right and left eyes for any of the variables $(P>0.05)$. There was wide variation in the biometric data for individuals of different ages and sizes, because the inclusion method was by convenience sample (Additional file 1). There were significant differences between species when comparing the same structures $(P<0.05)$ (Table 1$)$, mainly with respect to biometric measurements (Fig. 2). However, although there was a difference in the measured values of the ocular structures, the eyes did not present any significant dissimilarities. The width of the scleral ossicle was smaller for E. imbricata compared to the other species studied. The anterior chamber depth and ALL were significantly lower for E. imbricata compared to Caretta caretta and L. olivacea. The AGL was larger for Caretta caretta and L. olivacea than for the other two species. All intraocular structures were smaller in E. imbricata than in Caretta caretta. E. imbricata was the smallest species in terms of BW and carapace size, comprising a relatively young population.

Moderate to strong correlations $(r \geq 0.5)$ were found between almost all variables and BW and CCL in Caretta caretta and Chelonia mydas, except for SOT and BW in Caretta caretta and for SOT and CCL in both species (Additional file 2). Strong correlations $(r \geq 0.8)$ were seen between BW and CCL and between BW and CCW in all species, except for L. olivacea $(r \leq 0.3)$. Strong correlations $(r \geq 0.9)$ were present between $\mathrm{CCW}$ and $\mathrm{CCL}$ in all species. Moderate negative correlations were seen in $L$. olivacea between CCL and CT $(r=-0.6 ; P=0.034)$ and between CCL and ACD $(r=-0.7 ; \mathrm{P}=0.008)$. Moderate positive correlations in L. olivacea were seen between CCL and ALL $(r=0.7 ; \mathrm{P}=0.015)$ and between CCL and AGL $(r=0.7 ; P=0.024)$. In general, the highest echobiometric values were found in the largest animals.

\section{Discussion}

Several ultrasonographic studies have been performed on sea turtles to evaluate the coelomic cavity [25], but to the authors' knowledge, there are no reports on ophthalmic echobiometry in these species. However, the increasing number of sea turtles in conservation centres [14], and considering studies on ophthalmic diseases in these species $[10,12-15]$, there is rising concern among institutions and staff about the conservation of vision in these animals, to promote quality of life and allow for the possibility of reintroduction into a free living environment.

Ophthalmic examination of sea turtles has been reported to be difficult to perform due to high tear film viscosity, high corneal sensitivity, strong eyelid incursion, bulbar retraction, small pupil size, and a more complicated medical pupillary dilation than in many other species, even with the use of neuromuscular blockers such as vecuronium associated with phenylephrine or atracurium associated, or not, with atropine [14]. Ultrasound is a complementary modality for the diagnosis and followup of ophthalmic diseases because it enables evaluating the eye structures, even in the presence of opaque media [26] such as fibropapillomatosis, keratitis, ulcerations [13] and cataracts [15].

The high-frequency (10 and $12 \mathrm{MHz}$ ) linear transducer allowed the evaluation of the entire sea turtle eyeball, the size of which reached about $2 \mathrm{~cm}$ in depth. The contact surface of the transducer was $4.3 \mathrm{~cm}$, enabling a good view of the eyeball, but the orbital bone produced posterior acoustic shadowing that prevented visualization of the lateral part of the bulb and measurement of the equatorial diameter of the bulb. The use of a smaller transducer, such as a micro-convex 


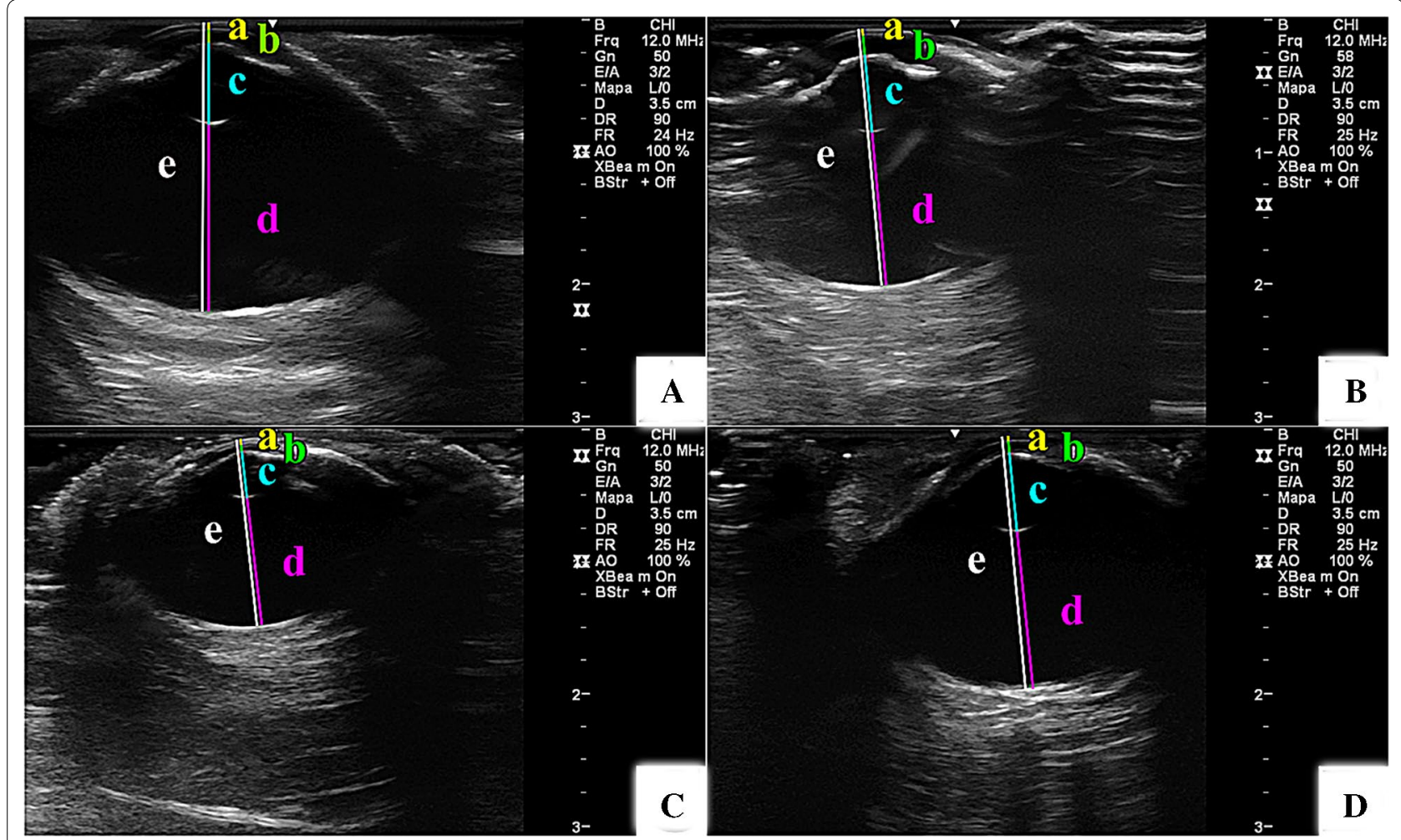

Fig. 2 Ultrasonographic images of the eyes of four different species of sea turtle with different body weights: Caretta caretta (A), Chelonia mydas (B), Eretmochelys imbricata $(\mathbf{C})$, and Lepidochelys olivacea (D), taken at the same transducer frequency and the same scale size (note the ruler to the right of each image). Similar structures at the level of the central optic axis are indicated by coloured lines as follows: corneal thickness (a), anterior segment depth (b), lens axial length (c), vitreous chamber depth (d), and axial globe length (e). Note the evident difference in size, especially the depth of the vitreous chamber and the axial length of the globe

transducer, would probably facilitate this measurement. Despite the fact that the equipment used in our study did not produce the degree of tissue resolution obtained by some specific ophthalmic ultrasonographic devices of higher frequencies, such as $21-48 \mathrm{MHz}$ [27], the images showed sufficient details for several clinical purposes. Moreover, the ultrasound machine was portable, and more accessible and affordable than nonportable ones, facilitating its use in different locations and even inside the enclosures, at the edge of the tanks where the larger animals live.

Thick scleral cartilage is related to the adaptive factors that prevent deformation of the eye bulb from water pressure during dives, and it also supports the bulb against extraocular muscle traction $[4,28,29]$. The scleral cartilage thickness in the study animals was similar to that found in other species of sea turtles by Brudenall et al. [4]. The larger measurements of the scleral ossicles found for Caretta caretta compared to L. olivacea may be assigned to the size difference of individuals between the groups. Moreover, the ossicles may not be the only factor providing protection against pressure on the eyeball, because $L$. olivacea has been reported to feed at greater depths than Caretta caretta [30].

The corneal thickness and the anterior chamber depth of the animals in this study were larger than what was found by Gornik et al. [10] for juvenile Kemp's ridley sea turtles (Lepidochelys kempii) using optical coherence tomography. Lower values for these structures were also found in frozen eyes of Chelonia mydas, Dermochelys coriacea and E. imbricata [31]. However, direct comparisons of values obtained using different evaluation methods should be made with caution, even for the same species, and the size of the study populations should be taken into consideration.

The sea turtle lens is more spherical in shape than that of semi-aquatic turtles [32], and this is closely related to the visual capacity of these animals $[15,32]$. Eretmochelys imbricata had smaller lenses than the other species studied, probably because the group of E. imbricata had the smallest individuals in size, and a strong correlation was seen between ALL and animal size. The lens was well assessed with the equipment used in this study and it is believed that structural changes, when present, could 
be easily detected, even when anterior segment opacification impaired visual inspection. This is reinforced by a previous study conducted with cataracts in sea turtles that used ultrasound as an auxiliary diagnostic tool.

The AGL values were positively correlated with animal size for all species studied here. Similar correlations have been described for other reptilian species, such as tortoises, caimans and iguanas [22, 32, 33]. The lack of correlation between AGL and animal size in L. olivacea is believed to be due to the fact that the evaluated individuals made up a population of relatively uniform size compared to the other species.

\section{Conclusions}

Ultrasonography proved to be practical and feasible to perform on the animals in this study, without any harmful effects on the individual, allowing indirect real-time visualization of intraocular structures. Only minor differences were found between the species in this study, reinforcing their phylogenetic proximity and their similar functions and habitats.

\section{Supplementary information}

Supplementary information accompanies this paper at https://doi. org/10.1186/s13028-020-00551-1.

Additional file 1. Shows the data of biometric and ecobiometric values per sea turtle.

Additional file 2: Table S1. Shows correlation values ( $r$; P-value) between body weight (BW) and curved carapace length $(\mathrm{CCL})$ with ultrasound measurements in sea turtle eyes.

\section{Abbreviations}

ACD: Anterior chamber depth; AGL: Axial globe length; ALL: Axial length of the lens; BW: Body weight; CCL: Curved carapace length; CCW: Curved carapace width; CT: Corneal thickness; MHz: Megahertz; SOT: Scleral ossicle thickness; SOW: Scleral ossicle width; UFBA: Federal University of Bahia; VC: Visitors centre; VCD: Vitreous chamber depth.

\section{Acknowledgements}

The authors are grateful to the Pro-TAMAR foundation. APO is a research fellow from the National Council for Scientific and Technological Development (CNPq). This study was financed in part by the Coordenação de Aperfeiçoamento de Pessoal de Nível Superior_Brasil (CAPES)_Finance Code 001. VCB is PhD student from CAPES (Coordenação de Aperfeiçoamento de Pessoal de Nível Superior)—Brazil, process code 88882.453698/2019-01 and ACR is a CAPES PhD fellow.

\section{Authors' contributions}

All authors were involved in designing the study. CM performed the ultrasonographic evaluation. All authors contributed in writing the manuscript. All authors read and approved the final manuscript.

\section{Funding}

This research did not receive any specific grant from funding agencies in the public, commercial, or not-for-profit sectors.

\section{Availability of data and materials}

The datasets analyzed during the current study are available from the corresponding author on reasonable request.

\section{Ethics approval and consent to participate}

The study was approved by the Authorization and Information System on Biodiversity, Brazilian Ministry of the Environment (50054-8), the National System of Genetic Heritage Management and Associated Traditional Knowledge (A1F8C27), and the Animal Ethics Committee of the Federal University of Bahia_UFBA (52/2016). It was conducted in accordance with the Association for Research in Vision and Ophthalmology (ARVO) Statement for the Use of Animals in Ophthalmic and Vision Research.

\section{Consent for publication}

Not applicable.

\section{Competing interests}

The authors declare that they have no competing interests.

\section{Prior publication}

Data have not been published previously.

\section{Author details}

${ }^{1}$ School of Veterinary Medicine and Zootechny, Federal University of Bahia, Avenida Adhemar de Barros, 500, Ondina, Salvador, BA 40170-110, Brazil.

${ }^{2}$ Fundação Pró-Tamar, Rua Rubens Guelli 134/ 307, Itaigara, Salvador, Bahia 41815-135, Brazil.

Received: 29 April 2020 Accepted: 3 September 2020

Published online: 10 September 2020

\section{References}

1. Avens L, Lohmann KJ. Use of multiple orientation cues by juvenile loggerhead sea turtles Caretta caretta. J Exp Biol. 2003;206:4317-25. https:// doi.org/10.1242/jeb.00657.

2. Constantino MA, Salmon M. Role of chemical and visual cues in food recognition by leatherback posthatchlings (Dermochelys coriacea L.). Zool. 2003;106:173-81. https://doi.org/10.1078/0944-2006-00114.

3. Southwood A, Higgins B, Brill R. Chemoreception in loggerhead sea turtles: an assessment of the feasibility of using chemical deterrents to prevent sea turtle interactions with longline fishing gear. In: US Department of Commerce, NOAA Technical Memorandum NOAA-TM-NMFSPIFSC-10. US Department of Commerce, Honolulu. 2007. https://www. researchgate.net/publication/237430704_Chemoreception_in_Logge rhead_Sea_Turtles_An_Assessment_of_the_Feasibility_of_Using_Chemi cal_Deterrents_to_Prevent_Sea_Turtle_Interactions_with_Longline_Fishi ng_Gear. Accessed 28 Aug 2020.

4. Brudenall DK, Schwab IR, Fritsches KA. Ocular morphology of the leatherback sea turtle (Dermochelys coriacea). Vet Ophthalmol. 2008;11:99-110. https://doi.org/10.1111/j.1463-5224.2008.00607.x.

5. Narazaki T, Sato K, Abernathy KJ, Marshall GJ, Miyazaki N. Loggerhead turtles (Caretta caretta) use vision to forage on gelatinous prey in mid-water. PLoS ONE. 2013;8:e66043. https://doi.org/10.1371/journal.pone.0066043.

6. Schuyler QA, Wilcox C, Townsend K, Hardesty BD, Marshall NJ. Mistaken identity? Visual similarities of marine debris to natural prey items of sea turtles. BMC Ecol. 2014;14:14. https://doi.org/10.1186/1472-6785-14-14.

7. Mathger $L$, Litherland $L$, Fritsches KA. An anatomical study of the visual capabilities of the green turtle Chelonia mydas. Copeia. 2007;2007:16979. https://doi.org/10.1643/0045-8511.

8. Sivak JG. Optics of amphibious eyes in vertebrates. In: Atema J, Fay RR, Popper AN, Tavolga WN, editors. Sensory biology of aquatic animals. Springer-Verlag: Berlin; 1988. p. 467-485.

9. Wyneken J. The anatomy of sea turtles. In: US Department of Commerce NOAA Technical Memorandum NMFS-SEFSC-470. Miami: National Marine Fisheries Service. 2001.

10. Gornik KR, Pirie CG, Marrion RM, Wocial JN, Innis CJ. Ophthalmic variables in rehabilitated juvenile Kemp's ridley sea turtles (Lepidochelys kempii). J Amer Vet Med Assoc. 2016;248:673-80. https://doi.org/10.2460/javma .248.6.673.

11. Jones J, Ariel E, Read M. A review of fibropapillomatosis in green turtles (Chelonia mydas). Vet J. 2016;212:48-57. https://doi.org/10.1016/j. tvjl.2015.10.041. 
12. Orós J, Torrent A, Calabuig P, Déniz S. Diseases and causes of mortality among sea turtles stranded in the Canary Islands, Spain (1998-2001). Dis Aquat Organ. 2005;63:13-24. https://doi.org/10.3354/dao063013.

13. İşler CT, Altuğ M, Cantekin Z, Özsoy ŞY, Yurtal Z, Deveci MZY. Evaluation of the eye diseases seen in loggerhead sea turtle (Caretta caretta). Rev Méd Vét. 2014;165:258-62. https://www.revmedvet.com/2014/RMV16 5_258_262.pdf. Accessed 28 Aug 2020.

14. Lively MJ, Westermeyer HD, Harms CA, Christiansen EF. Ophthalmic lesions in a population of cold-stunned sea turtles (Chelonia mydas, Lepidochelys kempii, Caretta caretta). Vet Ophthalmol. 2019;22:910-5. https ://doi.org/10.1111/vop.12672.

15. Westermeyer HD, Cook AG, Harms C, Boylan S. Phacoemulsification cataract surgery in the loggerhead turtle (Caretta caretta): surgical technique and outcomes in 10 cases. Vet Ophthalmol. 2019;22:644-50. https://doi. org/10.1111/vop.12635.

16. Flint M, Limpus CJ, Patterson-Kane JC, Murray PJ, Mills PC. Corneal fibropapillomatosis in green sea turtles (Chelonia mydas) in Australia. J Comp Pathol. 2010;142:341-6. https://doi.org/10.1016/j.jcpa.2009.10.012.

17. Seminoff JA, Southwest Fisheries Science Center, USA. Chelonia mydas. In: The IUCN Red List of Threatened Species. 2004: e.T4615A11037468.

18. Abreu-Grobois A, Plotkin P, IUCN SSC Marine Turtle Specialist Group. Lepidochelys olivacea. In: The IUCN Red List of Threatened Species. 2008: e.T11534A3292503.

19. Mortimer JA, Donnelly M, IUCN SSC Marine Turtle Specialist Group. Eretmochelys imbricata. In: The IUCN Red List of Threatened Species. 2008: e.T8005A12881238.

20. Casale P, Tucker AD. Caretta caretta (amended version of 2015 assessment). In: The IUCN Red List of Threatened Species. 2017: e.T3897A119333622.

21. Wallace BP, Tiwari M, Girondot M. Dermochelys coriacea. In: The IUCN Red List of Threatened Species. 2013: e.T6494A43526147.

22. Oriá AP, Silva RMM, Pinna MH, Oliveira AVD, Ferreira PRB, Martins Filho $E F$, et al. Ophthalmic diagnostic tests in captive red-footed tortoises (Chelonoidis carbonaria) in Salvador, northeast Brazil. Vet Ophthalmol. 2015;18:46-52. https://doi.org/10.1111/vop.12175.

23. Somma AT, Lima L, Lange RR, Turner-Giannico A, Montiani-Ferreira F. The eye of the red-eared slider turtle: morphologic observations and reference values for selected ophthalmic diagnostic tests. Vet Ophthalmol. 2015;18:61-70. https://doi.org/10.1111/vop.12213.

24. United States Department of the Interior, Fish and Wildlife Service. Standard permit conditions for care and maintenance of captive sea turtles.
2013:1-16. https://www.fws.gov/southwest/es/TexasCoastal/docs/ Forms/2013_Standard_Permit_Conditions_for_Captive_Sea_Turtles.pdf. Accessed 28 Aug 2020.

25. De Majo M, Macri F, Masucci M, Coci G, Pennisi MG. Clinical ultrasonography in loggerhead sea turtles (Caretta caretta): imaging of pathological features. Vet Med. 2016;61:155-61. https://doi.org/10.17221/8767-VETME D.

26. Wightman P, Pauwels F, Argandona AKG, Hunter S, Aguilar R. Use of ultrasonography and computed tomography in the diagnosis of panophthalmitis in a tuatara (Sphenodon punctatus). J Herp Med Surg. 2015;25:78-81. https://doi.org/10.5818/1529-9651-25.3.78.

27. Damsgaard C, Lauridsen H, Funder AMD, Thomsen JS, Desvignes T, Crossley DA, et al. Retinal oxygen supply shaped the functional evolution of the vertebrate eye. eLife. 2019;8:e52153. https://doi.org/10.7554/eLife .52153 .

28. Walls GL. The vertebrate eye and its adaptive radiation. In: Cranbrook Institute of Science, Bulletin no. 19. Cranbrook Institute of Science, Broomfield Hills. 1942. p. 276-612.

29. Pilleri G, Wandeler A. Ontogeny and functional morphology of eye of the fin whale (Balenoptera physalus). Acta Anatom. 1964;57:271-6.

30. Reis EC, Goldberg DW. Biologia, ecologia e conservação de tartarugas marinhas. In: Reis EC, Curbelo-Fernandez MP, editors. Mamíferos, quelônios e aves, 7: caracterização ambiental regional da Bacia de Campos, Atlântico Sudoeste. Elsevier: Rio de Janeiro; 2017. p. 63-89.

31. Northmore DP, Granda AM. Ocular dimensions and schematic eyes of freshwater and sea turtles. Visual Neurosci. 1991;7:627-35. https://doi. org/10.1017/s0952523800010415.

32. Oriá AP, Oliveira AVD, Pinna MH, Martins Filho EF, Estrela-Lima A, Peixoto TC, et al. Ophthalmic diagnostic tests, orbital anatomy, and adnexal histology of the broad-snouted caiman (Caiman latirostris). Vet Ophthalmol. 2015;18:30-9. https://doi.org/10.1111/vop.12115.

33. Araújo NLLC, Raposo ACS, Muramoto C, Meneses IDS, Bittencourt MV, Martins Filho EF, et al. Evaluation of selected ophthalmic diagnostic tests in green iguanas (Iguana iguana). J Exot Pet Med. 2017;26:176-87. https:// doi.org/10.1053/j.jepm.2017.05.009.

\section{Publisher's Note}

Springer Nature remains neutral with regard to jurisdictional claims in published maps and institutional affiliations.
Ready to submit your research? Choose BMC and benefit from:

- fast, convenient online submission

- thorough peer review by experienced researchers in your field

- rapid publication on acceptance

- support for research data, including large and complex data types

- gold Open Access which fosters wider collaboration and increased citations

- maximum visibility for your research: over 100M website views per year

At BMC, research is always in progress.

Learn more biomedcentral.com/submissions 